\title{
Aetiology of disturbed milk ejection in parturient primiparous cows*
}

\author{
BY RUPERT M. BRUCKMAIER, DIETER SCHAMS† AND JÜRG W. BLUM \\ Institut für Tierzucht der Universität Bern, CH-3012, Bern, Schweiz \\ $\dagger$ Institut für Physiologie der Süddeutschen Versuchs-und Forschungsanstalt für \\ Milchwirtschaft, Technische Universität München, W-8050 Freising-Weihenstephan, \\ Deutschland
}

(Received 3 October 1991 and accepted for publication 24 March 1992)

\begin{abstract}
Summary. Milk flow in nine primiparous cows with disturbed milk ejection (D) and in six corresponding control animals (C) with normal milk removal was recorded during machine milking and blood samples were taken before and during milking to determine plasma oxytocin, vasopressin, prolactin, cortisol, oestradiol-17 $\beta$, luteinizing hormone, progesterone and $\beta$-endorphin concentrations. Manual teat stimulation before milking lasted for $1 \mathrm{~min}$. After milk flow had stopped, air was blown into the vagina for $2 \mathrm{~min}$. When milk flow had stopped again, 1 i.u. oxytocin and finally 10 i.u. oxytocin were injected to remove residual milk. During and after teat stimulation, oxytocin remained basal in $\mathrm{D}$, but increased in $\mathrm{C}$, whereas prolactin increased in both groups. While $94 \%$ of total milk was obtained in $\mathrm{C}$ during this period, only $9 \%$ could be removed from $\mathrm{D}$, indicating lack of alveolar milk ejection. During vaginal stimulation, oxytocin increased transiently in $\mathrm{D}$ and more than by teat stimulation in $\mathrm{C}$. This allowed the removal of $75 \%$ of milk in $\mathrm{D}$, whereas almost no more milk was available in C. After oxytocin injections, 3 and $16 \%$ of residual milk were obtained in $\mathrm{C}$ and $\mathrm{D}$ respectively. Basal oestradiol $-17 \beta$ concentration was higher in $\mathrm{D}$ than in $\mathrm{C}(11 \cdot 6$ and $2 \cdot 0 \mathrm{ng} / \mathrm{l}$ respectively), whereas $\beta$-endorphin level was lower $(24 \cdot 1$ and $86 \cdot 6 \mu \mathrm{g} / \mathrm{l}$ respectively). Basal concentration of luteinizing hormone and progesterone, and concentration of cortisol and vasopressin before and during milking were comparable in $\mathrm{C}$ and $\mathrm{D}$. We conclude that in cows with disturbed milk ejection afferent nervous pathways to the hypothalamus were intact, because prolactin was released by teat stimulation. However, oxytocin was only released by vaginal stimulation, i.e. milk ejection was centrally inhibited during teat stimulation.
\end{abstract}

Teat stimulation evokes oxytocin $(\mathrm{OT})$ release from the posterior pituitary gland via a neuroendocrine reflex arc (Lincoln \& Paisley, 1982). After exceeding the threshold level, OT induces contraction of the myoepithelial cells surrounding the mammary alveoli and large milk ducts, thus forcing the alveolar milk fraction into the cistern cavity, accompanied by an increase of intramammary pressure (Schams et al. 1984; Mayer et al. 1991). Milk ejection is a necessary precondition for the availability of alveolar milk during milking.

Milk ejection in dairy cows can be disturbed in various situations. Disturbed milk removal is seen particularly in primiparous cows, and 2-3 out of 1000 animals demonstrate this problem in Switzerland (R. M. Bruckmaier and J.W. Blum,

* These results have been presented in part at the 83rd annual meeting of the American Society of Animal Science, 1991, in Laramie, WY, USA. An abstract of this presentation was published in Journal of Animal Science Suppl. 2, abstract no. 534. 
unpublished results). As $\sim 30 \%$ of all Swiss cows are primiparous, up to $1 \%$ of primiparous cows have disturbed milk removal. Inhibition of milk removal can be abolished by administration of OT, suggesting normal OT-receptor interaction in the mammary gland (Mielke \& Brabant, 1963; Schulz \& Brabant, 1970). The defect causing inhibition of milk ejection can be localized peripherally and/or centrally. Peripheral inhibition of milk ejection, i.e. disturbed action of the released OT in the mammary gland, can be mediated by catecholamines through $\alpha$-adrenergic receptors in mammary tissue and was experimentally induced in cows by the administration of catecholamines and $\alpha$-adrenergic agonists (Gorewit, 1978; Mielke, 1981 ; Lefcourt \& Akers, 1984 ; Gorewit \& Aromando, 1985 ; Blum et al. 1989; Bruckmaier et al. 1991; Bruckmaier \& Blum, 1992). Although milk removal was considerably disturbed during catecholamine administration and application of electroshocks caused rapid release of adrenaline and noradrenaline and a dramatically disturbed milk removal (Gorewit, 1978; Lefcourt \& Akers, 1984; Blum et al. 1989), OT responses to teat stimulation and during milking were not influenced (Lefcourt \& Akers, 1982; Blum et al. 1989). Obviously, blood plasma catecholamines do not reach the central nervous system to inhibit OT release and mediate their effects at the level of the mammary gland. However, central inhibition of milk ejection, i.e. lack of OT release from the pituitary during suckling, has been described in rabbits (Aulsebrook \& Holland, 1969; Tindal \& Blake, 1986), rats (Clarke et al. 1979; Wright, 1985) and mice (Haldar \& Sawyer, 1978; Haldar \& Bade, 1981) in association with high circulating concentrations of endogenous opioids thought to be responsible for the disturbance, since opioid antagonists were able to remove the inhibiting effect. Central inhibition of milk ejection in dairy cows, i.e. lack of O'T release during milking, has not to our knowledge definitely been shown.

The aim of the present work was to investigate the aetiology of disturbed milk removal in primiparous cows after parturition. Of special interest were responses of milk flow, O'T, prolactin (PRL) and of some other hormones to teat stimulation and vaginal stimulation.

\section{MATERIALS AND METHODS}

Primiparous cows with disturbed milk removal (group $\mathrm{D}, n=9$ ) and corresponding control animals with normal milk removal (group $\mathrm{C}, n=6$ ) were each tested once within $14 \mathrm{~d}$ post partum during evening milking. All animals were of the Simmental breed with different percentages of Red Holstein genes. Because of the relatively scarce appearance of disturbed milk removal, the experiments with group $D$ had to be performed on several farms within a $100 \mathrm{~km}$ radius around our research station during a half-year period from January to June. Experiments with group $\mathrm{C}$ were performed on our research station during October 1990. All animals were tethered. Experiments were performed in the animals' usual environment. The mean length of daylight and temperature were roughly comparable in the two groups.

As cows with disturbed milk removal obviously lacked alveolar milk ejection, several methods to induce milk ejection were tested sequentially. The milking cluster was applied after a 1 min manual teat stimulation. After milk flow had stopped (not earlier than 2 min after commencement of milking), vaginal stimulation lasting 2 min was performed by rhythmically blowing air into the vagina through soft plastic tubing. When milk flow had stopped again, 1.0 i.u. OT (E. Gräub AG, Bern) was injected intravenously (i.v.), followed before the end of milking by administration of $10 \mathrm{i}$.u. OT to remove the residual milk.

During the whole milking procedure, a strain gauge system was used for recording 
milk flow (Schams et al. 1984). The milk flow signal (weight gain differentiated by time) was continuously conveyed to a strip chart recorder.

Before the experiments an indwelling catheter was inserted into the right jugular vein for collection of blood samples $(10 \mathrm{ml}$ ) at $1 \mathrm{~min}$ intervals (from $2 \mathrm{~min}$ before manual teat stimulation until the i.v. injection of 10 i.u. OT at the end of milking). Blood samples were treated with heparin (50 USP units $/ \mathrm{ml}$ blood) to prevent coagulation, cooled on ice and centrifuged immediately after the experiment and the plasma was stored at $-20^{\circ} \mathrm{C}$ in several portions for determination of hormones, total $\mathrm{Ca}$, total $\mathrm{Mg}$ and inorganic $\mathrm{P}\left(\mathrm{P}_{\mathrm{i}}\right)$.

Oxytocin concentration was determined radioimmunologically (Schams et al. 1982 ; Schams, 1983) after extraction with SEP-PAK C18 cartridges. Detection limit was $<0.5 \mathrm{pg} / \mathrm{ml}$ plasma. Cross reactivity with other proteins (vasopressin) was $<0 \cdot 1 \%$. Intra-assay variation was $<8 \%$, inter-assay variation $12 \%$.

Arginine vasopressin (antidiuretic hormone) was determined by radioimmunoassay using a kit (Bühlmann Laboratories AG, Basel). To enhance the sensitivity of the assay (detection limit $0.2 \mathrm{pg} / \mathrm{ml}$ ), plasma $(0.5 \mathrm{ml})$ was extracted with $2.5 \mathrm{ml}$ ethanol $\left(-20^{\circ} \mathrm{C}, 98 \%\right)$. After centrifugation, decanting and drying the supernatant under vacuum at $37^{\circ} \mathrm{C}$, the extract was dissolved in $0.25 \mathrm{ml}$ phosphate buffer and $0.2 \mathrm{ml}$ of this solution was used in the assay. Cross reactivity with lysine vasopressin was $0.25 \%$, with oxytocin and vasotocin $<0.001 \%$.

Concentrations of bovine PRL were determined radioimmunologically by a double antibody method. Plasma $(0.1 \mathrm{ml})$ was incubated for $24 \mathrm{~h}$ at $4{ }^{\circ} \mathrm{C}$ with $0.1 \mathrm{ml}$ antiserum (raised against ovine PRL in a rabbit (NIDDK-anti-ovine PRL-2, final dilution 1:500000, kindly provided by Dr Salvatore Raiti, University of Maryland, Baltimore,. MD 21201, USA)), $0.2 \mathrm{ml} 25 \mathrm{~mm}$-Tris-10 $\mathrm{mm}^{-\mathrm{CaCl}_{2}}$ buffer, pH $7 \cdot 2$ containing $0.2 \% \mathrm{NaN}_{3}$ and $2 \%$ bovine serum albumin, and ${ }^{125}$ I-labelled PRL. Then $0.1 \mathrm{ml}$ normal rabbit serum and second antibody (goat anti-rabbit serum, 1:50) were added and the mixture was incubated for another $20 \mathrm{~h}$, after which $0.5 \mathrm{ml}$ polyethyleneglycol $(6 \%)$ was added. The tubes were then centrifuged $(3000 \mathrm{~g}$, $30 \mathrm{~min}$ ) to separate free and antibody-bound ${ }^{125} \mathrm{I}-\mathrm{PRL}$. The sensitivity of the assay was $0.25 \mu \mathrm{g} / \mathrm{l}$ and $50 \%$ inhibition of binding was at $10 \mathrm{ng} / \mathrm{ml}$. Bovine PRL was used as a standard preparation (NIH-P-B ${ }_{3}$ ). Intra-assay variation was $<5 \%$; inter-assay variation was $<12 \%$. Cross reactivity with bovine growth hormone was $<0.1 \%$.

Concentrations of cortisol were determined by radioimmunoassay as described by Blum et al. (1985). The sensitivity of the assay was $1 \mu \mathrm{g} / \mathrm{l}$. In addition, baseline concentrations of oestradiol-17 $\beta$ (Schallenberger et al. 1985), luteinizing hormone (Mutayoba et al. 1990) and progesterone (Prakash et al. 1987) were determined by enzyme immunoassay in pre-milking blood samples.

Baseline concentrations of $\beta$-endorphin were determined by radioimmunoassay using a kit (Incstar Corporation 46065, Stillwater, MN 55082, USA). The method has been shown to be suitable for the determination of $\beta$-endorphin in cattle (technical note). Cross reactivity with $\beta$-lipotropin was $5 \cdot 6 \%$, with other opioids $0 \cdot 1 \%$.

Baseline concentrations of $\mathrm{Ca}, \mathrm{Mg}$ and $\mathrm{P}_{\mathrm{i}}$ were determined by Professor. $\mathrm{Dr}$ : P. Tschudi, Clinic for Large Animals, University of Bern, using atomic absorption and conventional spectrophotometric methods.

\section{Statistical analyses}

Results were statistically evaluated using the SAS program package (release 6.04) (SAS, 1987). For presentation and calculation of hormone results, mean values for periods of $2 \mathrm{~min}$ were calculated before the start of teat stimulation (two blood 

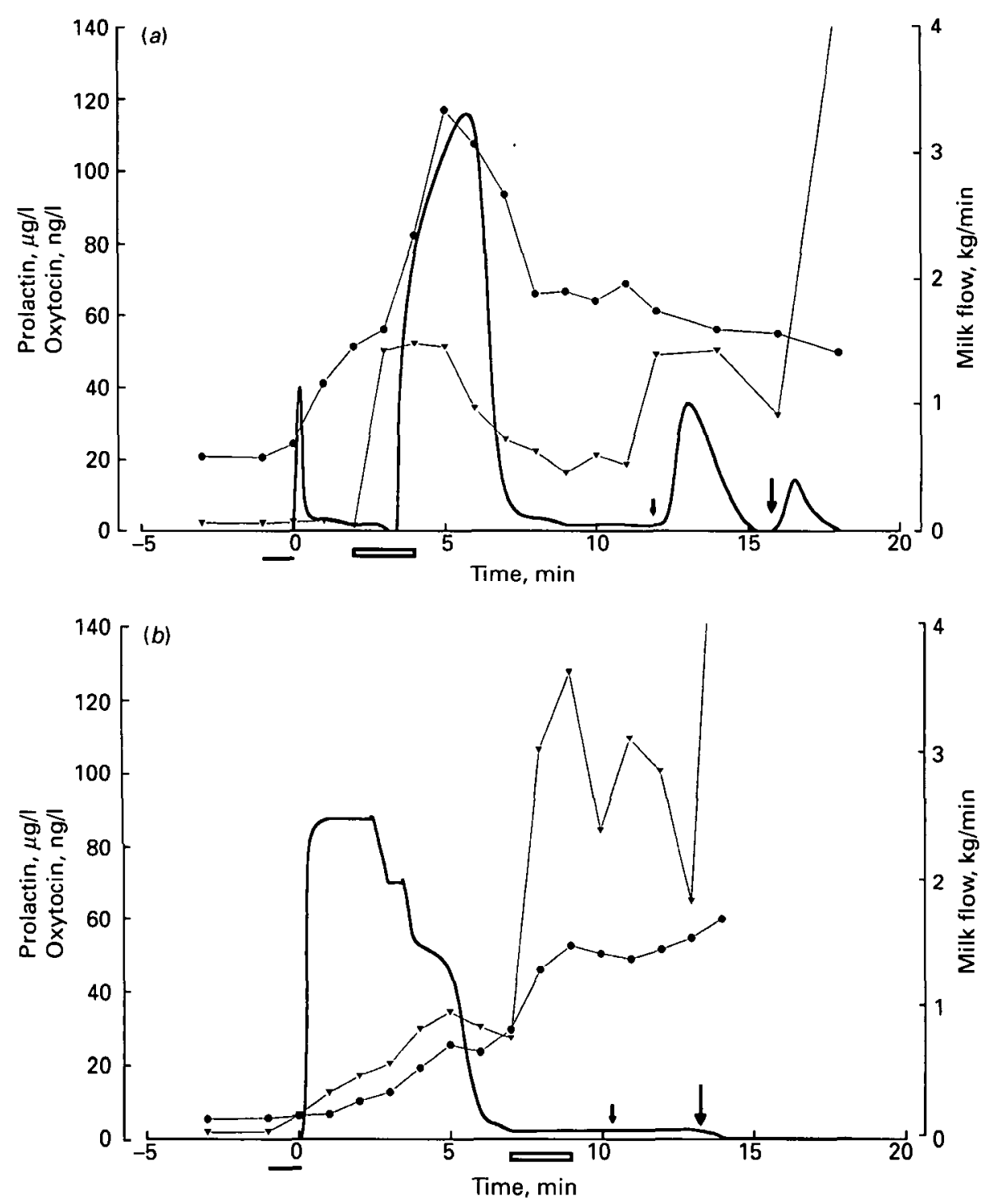

Fig. 1. Concentrations of oxytocin ( $\boldsymbol{\nabla})$ and prolactin (O) and milk flow rate $(-)$ before and during milking in $(a)$ a cow with disturbed milk flow and $(b)$ a cow with normal milk removal. - Teat stimulation; , vaginal stimulation; 0 , start of milking; small arrow, i.v. injection of 1 i.u. oxytocin; large arrow, i.v. injection of 10 i.u. oxytocin.

samples, phase I), from the end of teat stimulation and the start of milking (three blood samples, phase II), from 1 min after the start of vaginal stimulation (three blood samples, phase III) and 2 min before the end of milking (three blood samples, phase IV). Values are presented as means \pm sEM. Changes during the course of the experiment (dependent samples) were tested for significance $(P<0.05)$ by means of Wilcoxon's signed rank test. Differences between animal groups (independent samples) were tested for significance $(P<0.05)$ by the Mann-Whitney U-test. 


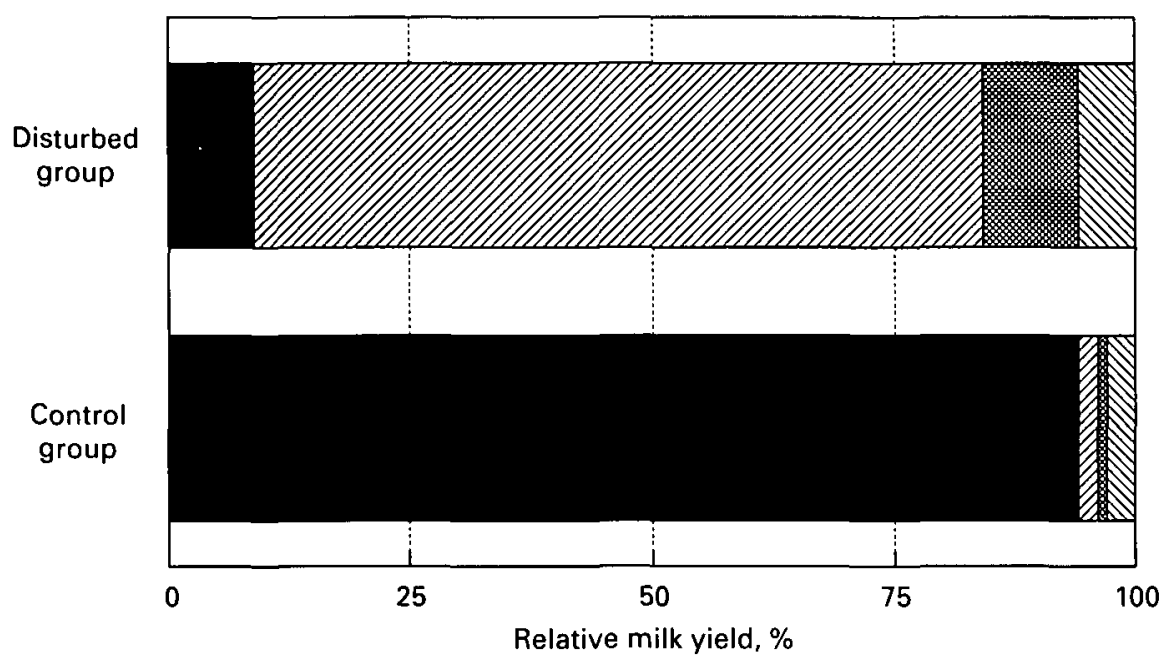

Fig. 2. Relative milk yields in response to succeeding methods used to stimulate milk ejection in cows with disturbed milk flow and normal control cows: $\square$, teat stimulation; $\square$, vaginal stimulation; $\square$, i.v. injection of 1 i.u. oxytocin; $\mathbb{\$}$, i.v. injection of $10 \mathrm{i} . u$. oxytocin.

\section{Milk yields}

RESULTS

Mean total yields at experimental milkings (in the evening) were $9 \cdot 2 \pm 1 \cdot 0$ and $8 \cdot 6 \pm 0 \cdot 6 \mathrm{~kg}$ in groups D and C respectively. As shown in Fig. 1 $a, b$ and Fig. 2, in group D only $9 \pm 4 \%$ of total milk was obtained in response to teat stimulation and normal milking, whereas $94 \pm 1 \%$ of total milk was obtained in group C. In response to subsequent vaginal stimulation, $75 \pm 7$ and $2 \pm 1 \%$ were removed in groups D and C respectively. After administration of $1 \mathrm{i}$.u. OT, $10 \pm 5$ and $1 \pm 0.5 \%$, and after injection of $10 \mathrm{i} . \mathrm{u}$. OT, $6 \pm 2$ and $3 \pm 0.6 \%$ of total milk could be removed in groups $\mathrm{D}$ and $\mathrm{C}$ respectively. Milk flow rates and milk yield in response to vaginal stimulation and OT injection in group $D$ were comparable to normal milkings after disappearance of the disturbance 2 or 3 weeks later (results not shown).

\section{Oxytocin}

OT concentrations (Fig. 1 $a, b$, Table 1) before manual teat stimulation (phase I) were low in groups D and C, although slightly and significantly higher in group D than C. During teat stimulation and start of milking (phase II), OT concentrations remained at the basal level in group $\mathrm{D}$, but increased significantly and remained elevated during the whole milking procedure in group C. During and after vaginal stimulation (phase III), OT concentrations started to increase in group D, but increased in group $\mathrm{C}$ to higher levels than in group D and significantly more than during teat stimulation. At $1 \mathrm{~min}$ after i.v. injection of 1 i.u. OT, concentrations of OT increased to $72 \pm 25 \mathrm{ng} / \mathrm{l}$ and after administration of $10 \mathrm{i} . \mathrm{u}$. OT (phase IV) to 400 $500 \mathrm{ng} / \mathrm{l}$ in both groups.

\section{Prolactin}

During phase I, PRL concentrations were higher in group D than in group C (Table 1). During phase II, PRL increased markedly in group D, but only slightly in group C. Mean PRL concentrations increased further during the whole machine-on time in both groups, and in group $\mathrm{C}$ were also significantly elevated during phase III 


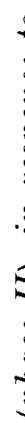

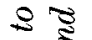

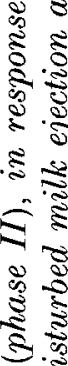

เั

$\frac{2}{8}$

.

ঙ

is

守

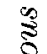

요

๑

है है

के

ลี

-

$\sqrt{2} 8$

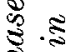

\&

ธิ์

空

(ิ)

क

ป

ए

क्षे

8

की

2.

จ

$\stackrel{8}{\circ}$

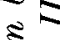

85

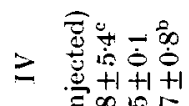

过

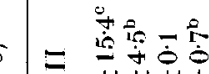

= $+1+1+1+1$ 官昜

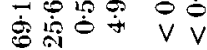

ह 客客 SS

क.

$\frac{1}{2}$

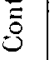

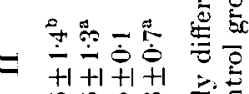
ఏ용요

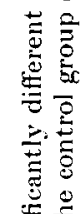

.$\frac{50}{60} .5$

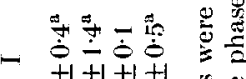

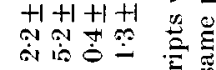

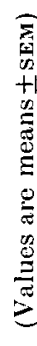

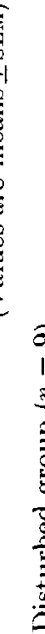
要它

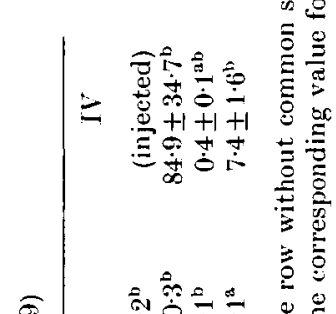

$\sigma$
II
$\Xi$ 客宫熍

ปั

จ 3 हे

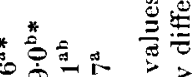

$=\begin{aligned} & \dot{0} \dot{0} \dot{0} \\ & +1+1+1\end{aligned}$ $\infty \infty+6$

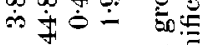

\% ซิ

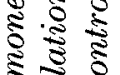

约

量

के है

ब ब

Q

त

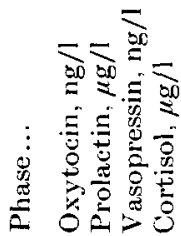


Table 2. Pre-milking concentrations of hormones and minerals in blood plasma of a group of cows with disturbed milk ejection and a normal control group

(Values are means \pm SEM)

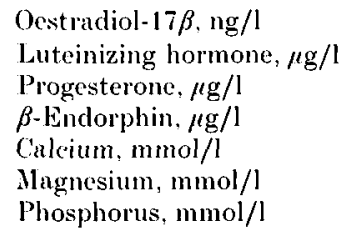

Disturbed group $(n=9) \quad$ Control group $(n=6)$

$\begin{array}{cc}11 \cdot 6 \pm 0 \cdot 9^{*} & 2 \cdot 0 \pm 0 \cdot 3 \\ 0 \cdot 7 \pm 0 \cdot 1 & 0 \cdot 5 \pm 0 \cdot 1 \\ <0 \cdot 2 & <0 \cdot 2 \\ 24 \cdot 1 \pm 7 \cdot 6^{*} & 86 \cdot 6 \pm 15 \cdot 1 \\ 2 \cdot 5 \pm 0 \cdot 1 & 2 \cdot 3 \pm 0 \cdot 1 \\ 0 \cdot 9 \pm 0 \cdot 1 & 0 \cdot 8 \pm 0 \cdot 1 \\ 1 \cdot 5 \pm 0 \cdot 1 & 1 \cdot 3 \pm 0 \cdot 1\end{array}$

* Values were significantly different from the control group mean $(P<0 \cdot 05)$.

and phase IV. During the whole milking procedure, mean PRL values remained higher in group D than in group C.

\section{Other hormones}

Vasopressin concentrations were at similar low levels in both experimental groups and remained low during the whole course of milking (Table 1), although there was a tendency to increase during teat and vaginal stimulation (significant in group D, phase III).

Cortisol concentrations were similarly low before teat stimulation (phase I) in both experimental groups, increased slowly during the course of milking, and were significantly elevated at the end of milking (phase IV) in both groups (Table 1).

Baseline concentrations of oestradiol-17 $\beta$ were dramatically elevated in group D compared with group $C$, whereas concentrations of luteinizing hormone were similarly low and progesterone values were below detection limit $(0 \cdot 2 \mu \mathrm{g} / \mathrm{l})$ in both groups (Table 2). Baseline concentrations of $\beta$-endorphin were considerably lower in group $\mathrm{D}$ than in group $\mathrm{C}$.

\section{Minerals}

Baseline concentrations of $\mathrm{Ca}, \mathrm{Mg}$ and $\mathrm{P}_{\mathrm{i}}$ (Table 2) were in the normal range and did not differ between experimental groups.

\section{DISCUSSION}

Cows with disturbed milk removal were characterized by normal basal concentrations (phase I) of $\mathrm{OT}^{\mathrm{T}} \mathrm{T}$, vasopressin, cortisol, luteinizing hormone, progesterone, $\mathrm{Ca}$ and $\mathrm{Mg}$ and $\mathrm{P}_{\mathrm{i}}$, but higher levels of PRL and oestradiol-17 $\beta$ and low concentrations of $\beta$-endorphin. The higher baseline concentrations of PRL in group $D$ than in group $C$ were probably an expression of seasonal differences of PRL release (Schams \& Reinhardt, 1974), since experiments with group D were performed between January and June, whereas control experiments were performed during October. Hypocalcaemia alone or combined with hypomagnesaemia, which can cause inhibition of milk ejection, could be excluded as underlying causes in our study.

During teat stimulation and early milking (phase II), OT in group C increased beyond the threshold level necessary to evoke alveolar milk ejection (Schams et al. 1984; Mayer et al. 1991), and remained elevated, because machine milking is known to act as a stimulus for OT release (Schams et al. 1984; Gorewit \& Gassman, 1985). OT release during teat stimulation and machine milking in normal cows has been 
shown to be more marked in early stages of lactation than in mid lactation (Lefcourt \& Akers, 1991; Mayer et al. 1991). In contrast, OT remained at baseline concentration, i.e. below threshold level, during and after teat stimulation in group D. To our knowledge this is the first demonstration of central inhibition of O'T release in the dairy cow and the first time that lack of OT release was found to be associated with disturbed milk removal in primiparous cows. While most of the milk yield was removed during and after teat stimulation in group $\mathrm{C}$ (phase II), milk ejection did not occur in group $D$ and hence only a very small amount of milk, presumably the cisternal milk fraction, was available. In contrast to OT, concentrations of PRL and cortisol started to increase during phase II and further increased until the end of milking in groups $\mathrm{C}$ and $\mathrm{D}$. This indicates that signal transmission from the mammary gland to the hypothalamus for release of PRL and corticotropin-releasing factors (Dufy-Barbe, 1985) was intact in both experimental groups. It was shown previously (Reinhardt \& Schams, 1974; Sagi et al. 1980) that PRL increases continuously during the course of teat stimulation or milking. Cortisol, too, typically increases during milking (Koprowski \& Tucker, 1973). In contrast to OT, concentrations of vasopressin, which is synthesized together with O'T in the hypothalamus (Dufy-Barbe, 1985), remained similarly low $(<1 \mathrm{ng} / \mathrm{l})$ during the whole experiment in both groups. The small increase of vasopressin was negligible compared with the marked rise seen during treadmill exercise of calves, in which concentrations up to $32 \mathrm{ng} / \mathrm{l}$ were measured (R. M. Bruckmaier and J. W. Blum, unpublished results). From the vasopressin results, there were no indications of a possible defect at the level of the posterior pituitary associated with reduced milk removal. Furthermore, peripheral inhibition of milk ejection by high concentrations of vasopressin, as found in rabbits (Tindal \& Blake, 1986), was most unlikely in this investigation. The results also confirmed that during milking vasopressin behaves very differently from OT.

In response to vaginal stimulation (phase III), OT concentrations increased in group D and further increased in group C. Vaginal stimulation has been found to be a more potent stimulus for OT release than teat stimulation (Schams et al. 1982). As OT concentrations in group D did not increase at all during teat stimulation and tended to rise less than in group $\mathrm{C}$ in response to vaginal stimulation, a stronger neuronal signal was obviously necessary in group D to stimulate the release of OT. Less probably, afferent neuronal pathways to the hypothalamus, originating in the mammary gland and vaginal area respectively, may be different, and if this is so the pathway from the mammary gland may not have been completely functional in group D. Most of the milk in the udder could be removed in response to vaginal stimulation in group D owing to sufficient OT release, whereas milk could barely be obtained in group $\mathrm{C}$ because most of the milk had already been removed following teat stimulation. Since no additional OT was released by machine milking in group $\mathrm{D}$ following vaginal stimulation, O'T concentrations decreased. Therefore, and owing to collapse of milk ducts by long overmilking periods, milk removal was still not complete in group D. Moreover, the present results also indicate that O'T concentrations must be continuously above the threshold level during milking for complete milk removal.

Because of incomplete milk removal during teat and vaginal stimulation in group $\mathrm{D}$, the administration of 1 and 10 i.u. OT allowed further milk removal. Since the administration of 1 i.u. OT, which raised plasma OT concentrations to the upper physiological level, allowed almost complete milk removal, myoepithelial cells were normally sensitive and responsive to OT in group D. In contrast to group D, almost 
no milk could be obtained in group $\mathrm{C}$ in response to $\mathrm{OT}$ injections. This demonstrates that with manual and machine teat stimulation almost complete removal of milk was possible in this group.

As milk flow and milk yield in response to vaginal stimulation and OT injection was normal in group D, peripheral inhibition of milk removal, such as caused by endogenous or exogenous catecholamines (Gorewit, 1978; Mielke, 1981; Lefcourt \& Akers, 1984; Gorewit \& Aromando, 1985; Blum et al. 1989; Bruckmaier et al. 1991), was probably not involved in the inhibition of milk ejection in group D. Blum et al. (1989) and Lefcourt \& Akers (1982) found an increase of blood plasma catecholamine concentrations and a considerable inhibition of milk removal, but normal $O T$ release, in response to teat stimulation and milking after electroshock treatments. Therefore, the reduced milk removal during emotional stress, at least based on responses to electroshock, is mainly mediated by peripheral mechanisms, whereas the inhibition of OT release and milk ejection in the present study seems to be exclusively central. From the evidence of cortisol levels, cows of group D were not emotionally stressed.

Concentrations of oestradiol- $17 \beta$ in primiparous and older cows are normally as low as found in group $\mathrm{C}$ at $2 \mathrm{~d}$ after parturition (Pope, 1982 ; Schallenberger \& Walters, 1985). Sexual cycle activity with elevated concentrations of oestradiol-17 $\beta$ is observed not earlier than $\sim 2$ weeks post partum. Causes and the relevance (if any) to milk removal of the very high oestradiol-17 $\beta$ concentrations in cows of group $D$ are not known. However, it is well known that high oestradiol-17 $\beta$ concentrations during the sexual cycle are occasionally associated with inhibition of milk ejection. Disturbance of milk removal could not be elicited by injection of oestradiol-17 $\beta$ in one normal milking primiparous cow (results not shown). As disturbance of milk removal in cows of group D mostly disappeared suddenly within 2 weeks, this may be in association with new cyclic activity. In one cow of group $\mathrm{D}$, milk removal became normal as soon as she was successfully inseminated (results not shown).

Elevated concentrations of $\beta$-endorphin are thought to be responsible for delayed cyclic activity by suppressing gonadotropin-releasing hormone and luteinizing hormone release in cattle (Myers et al. 1989; Barb et al. 1991). Blood plasma, i.e. peripheral $\beta$-endorphin concentrations, which are expected to mirror at least to some extent the concentrations in the central nervous system, were diminished in group $\mathrm{D}$ in our study. Reduced $\beta$-endorphin concentrations may be a possible reason for early cyclic activity in these animals. However, in this respect our endocrine results are confusing, as concentrations of luteinizing hormone and progesterone were very similar in both experimental groups, not indicating evidence for sexual cyclicity. High endogenous opioid concentrations were shown to be responsible for inhibition of oxytocin release in rabbits (Aulsebrook \& Holland, 1969), rats (Clarke et al. 1979; Wright, 1985) and mice (Haldar \& Sawyer, 1978; Haldar \& Bade, 1981). The relevance, if any, of the reduced $\beta$-endorphin concentrations in our study to inhibition of OT release is not clear.

In conclusion, the disturbed milk removal in primiparous cows was obviously caused by central inhibition of milk ejection, i.e. lack of OT release in response to teat stimulation and milking. Causes and roles of high blood concentrations of PRL, oestradiol-17 $\beta$ and low circulating $\beta$-endorphin levels for milk removal need to be further investigated.

This study was supported by the Swiss National Foundation (Grant 3228781.90). We thank Mr F. Jans, Eidg. FA Grangeneuve, Posieux, Professor Dr J. Martig, Klinik für Nutztiere und Pferde, Universität Bern, Dr Perritaz, Farvagny- 
le-Petit and Drs E. Schneider and W. Lauenberger, Affoltern i.E. for referring the clinical cases. We thank Professor Dr P. Tschudi for measuring Ca, Mg and P. The expert performance of hormone assays by Ms C. Braun, Institut für Physiologie, Technische Universität München and by Ms C. Morel and Ms Y. Zbinden, Institut für Tierzucht, Universität Bern, is greatly appreciated. We thank the various veterinarians for participating in the inquiry on inhibition of milk removal. We thank Dr S. Raiti, Baltimore, MD, USA, for providing us with PRL and antibody to PRL. Kits used for the determination of vasopressin and $\beta$-endorphin were gifts from Bühlmann Laboratories (Basel) and Incstar Corporation respectively. Parts of the milking equipment were a present from the Westfalia Separator AG, Oelde.

\section{REFERENCES}

Aulsebrook, L. H. \& Holland, R. C. 1969 Central inhibition of oxytocin release. American Journal of Physiology 216 830-842

Barb, C. R., Kraeling, R. R. \& Rampacek, G. B. 1991 Opioid modulation of gonadotropin and prolactin secretion in domestic farm animals. Domestic Animal Endocrinology $815-27$

Blum, J. W., Jans, F., Moses, W., Fröhli, D., Zemp, M., Wanner, M., Hart, 1. C., 'Thun, R. \& K hller, U. 1985 Twentyfour-hour pattern of blood hormone and metabolite concentrations in high-yielding dairy cows: effects of feeding low or high amounts of starch, or crystalline fat. Zentralblatt für Veterinärmedizin $A 32$ $401-418$

Blum, J. W., Schams, D. \& Bruckmaler, R. 1989 Catecholamines, oxytocin and milk removal in dairy cows. Journal of Dairy Research 56 167-177

Bruckmaier, R. II. \& Blum, J. W. 1992 B-mode-ultrasonography of mammary glands of cows, goats and sheep during $\alpha$ - and $\beta$-adrenergic agonist and oxytocin administration. Journal of Dairy Research 59 151-159

Bruckmaier, R., Mayer, H. \& Schais, D. 1991 Effects of $\alpha$-and $\beta$-adrenergic agonists on intramammary pressure and milk flow in dairy cows. Journal of Dairy Research $58+11-419$

Clarke, G., Wood, P., Merrick, L. \& Linoots, D. W. 1979 Opiate inhibition of peptide release from the neurohumoral terminals of hypothalamic neurones. Nature $282746-748$

DUFY-BARBE, L. 1985 Hypothalamic hormones. Endeavour $942-51$

Gonewit, R. C. 1978 Effect of epinephrine hydrochloride on oxytocin release and milk yield in lactating cattle. Journal of Dairy Science 61 Suppl. 1148

Gonewit, R. C. \& Aromando, M. C. 1985 Mechanisms involved in the adrenalin-induced blockade of milk ejection in dairy cattle. Proceedings of the Society for Experimental Biology and Medirine $180340 \quad 347$

Gorewit, R. C. \& Gassman, K. B. 1985 Effects of duration of udder stimulation on milking dynamics and oxytocin release. Journal of Dairy Science 68 1813-1818

HALDAR, J. \& BADE, V.1981 Involvement of opioid peptides in the inhibition of oxytocin release by heat stress in lactating mice. Proceedings of the Society for Experimental Biology and Nedicine 168 10-14

HALdAR, J. \& SAWYer, W. H. 1978 Inhibition of oxytocin release by morphine and its analogs. Proceedings of the Society for Experimental Biology and Medicine $157476-480$

Koprowsk, J.A. \& Tucker, H. A. 1973 Bovine serum growth hormone, corticoids and insulin during lactation. Endocrinology 93 645-651

LefCour', A. M. \& Akers, R. M. 1982 Endocrine responses of cows subjected to controlled voltages during milking. Journal of Dairy Science $652125-2130$

LefCoUR', A. M. \& AKERS, R. M. 1984 Small increases in peripheral noradrenalin inhibit the milk-ejection response by means of a peripheral mechanism. Journal of Endocrinology 100 337-344

Lefrourt, A. M. \& Akers, R. M. 1991 Teat stimulation-induced oxytocin and catecholamine release in pregnant and lactating Holstein heifers. Domestic Animal Endocrinology 8 235-243

Lincoln, D. W. \& PAtSLey, A. C. 1982 Neuroendocrine control of milk ejection. Journal of Reproduction and Fertility $65571-586$

Mayer, H., Bruckmaier, R. \& Schams, D. 1991 Lactational changes in oxytocin release, intramammary pressure and milking characteristics in dairy cows. Journal of Dairy Research 58 159-169

Mielke, H. 1981 [Recent results from studies on inhibited milk ejection.] Monatshefte für Veterinärmedizin 36 $525-530$

Mielke, H. \& Brabant, W. 1963 [Permanent disorder of normal unconditioned milk ejection reflex in lactating cows. 1 and 2.] Monatshefte für Veterinärmedizin 18 451-457, 493-499

Mutayoba, B. M., Meyer, H. H. D., Schams, D. \& Schallenberger, E. 1990 Development of a sensitive enzyme immunoassay for LH determination in bovine plasma using the streptavidin-biotin technique. Acta Endocrinologica 122 227-232

Myers, 'T. R., Myers, D. A., GregG, D. W. \& Moss, G. E. 1989 Endogenous opioid suppression of relcase of luteinizing hormone during suckling in postpartum anestrous beef cows. Domestic Animal Endocrinology 6 183-190 


\section{Disturbed milk ejection in cows}

Pope, G. S. 1982 Oestrogens and progesterone in plasma and milk of post-partum dairy cattle. In Factors Influencing Fertility in the Postpartum Cow, pp. 248-276 (Eds H. Karg and E. Schallenberger). The Hague: Martinus Nijhoff (Current Topics in Veterinary Medicine and Animal Science 20)

Prakash, B. S., Meyer, H. H. D., Schallenberger, E. \& van de Wied, D. F. M. 1987 Development of a sensitive enzymeimmunoassay (EIA) for progesterone determination in unextracted bovine plasma using the second antibody technique. Journal of Steroid Biochemistry 28 623-627

ReinhardT, V. \& Schans, D. 1974 Analysis of teat stimulation as specific stimulus for prolactin in cattle. Neuroendocrinology 14 289-296

SaGi, R., Gorewit, R. C., Merrild, W. G. \& Wilson, D. B. 1980 Premilking stimulation effects on milking performance and oxytocin and prolactin release in cows. Journal of Dairy Science 63 800-806

SAS, 1987 SAS Users' Guide: Statistics Cary, NC: SAS Institute

Schallenberger, E., Schöndorfer, A. M. \& Walters, D. L. 1985 Gonadotrophins and ovarian steroids in cattle. I. Pulsatile changes of concentrations in the jugular vein throughout the oestrus cycle. Acta. Endocrinologica 108 312-321

SChallanberger, E. \& WAlters, D. L. 1985 Endocrine mechanisms contributing to postpartum anoestrus in dairy and beef cattle. In Endocrine Causes of Seasonal and Lactational Anestrus in Farm Animals (Eds E. Ellendorf and F. Elsaesser). Dordrecht: Martinus Nijhoff

Schass, D. 1983 Oxytocin determination by radioimmunoassay. III. Improvement to subpicogram sensitivity and application to blood levels in cyclic cattle. Acta Endocrinologica 103 180-183

Schams, D., Baumans, G. \& LeIDL, W. 1982 Oxytocin determination by radioimmunoassay in cattle. 11. Effect of mating and stimulation of the genital tract in bulls, cows and heifers. Acta Endocrinologica $99218-223$

Schams, D., MaYer, H., Prokopp, A. \& WorstorfF, H. 1984 Oxytocin secretion during milking in dairy cows with regard to the variation and importance of a threshold level for milk removal. Journal of Endocrinology $102337-343$

Schams, D. \& ReinhardT, V. 1974 Influence of the season on plasma prolactin level in cattle from birth to maturity. Hormone Research 5 217-226

Schulz, J. \& Brabast, W. 1970 [Disorders of the unconditioned milk-ejection reflex in cows.|Monatshefte für Veterinärmedizin $2557-58$

TINDAL, J.S. \& BLAKE, L. A. 1986 Central inhibition of oxytocin release in the rabbit: role of the midbrain. Journal of Endocrinology 109 405-409

Wriont, D. M. 1985 Evidence for a spinal site at which opioids may act to inhibit the milk-ejection reflex. Journal of Endocrinology $106401-407$ 